\title{
Chitinolytic Microorganisms and Their Possible Application in Environmental Protection
}

\author{
Maria Swiontek Brzezinska • Urszula Jankiewicz • \\ Aleksandra Burkowska $\cdot$ Maciej Walczak
}

Received: 9 April 2013/ Accepted: 5 July 2013/Published online: 29 August 2013

(C) The Author(s) 2013. This article is published with open access at Springerlink.com

\begin{abstract}
This paper provides a review of the latest research findings on the applications of microbial chitinases to biological control. Microorganisms producing these enzymes can inhibit the growth of many fungal diseases that pose a serious threat to global crop production. Currently, efforts are being made to discover producers of chitinolytic enzymes. The potential exists that natural biofungicides will replace chemical fungicides or will be used to supplement currently used fungicides, which would reduce the negative impact of chemicals on the environment and support the sustainable development of agriculture and forestry.
\end{abstract}

\section{Introduction}

Plant diseases are a major problem facing plant cultivation and are responsible for the loss of $10 \%$ of the total global crop production [98]. Molds, one of the most aggressive plant pathogens, are conventionally destroyed with chemical fungicides. Their widespread use, which has tripled over the last 40 years, has accelerated environmental pollution and degradation. Moreover, chemical fungicides may be lethal to beneficial insects and microorganisms populating the soil and may enter the food chain [9]. Despite their high effectiveness and ease of use, chemical

M. Swiontek Brzezinska $(\bowtie) \cdot$ A. Burkowska $\cdot$ M. Walczak Department of Environmental Microbiology and Biotechnology, Faculty of Biology and Environmental Protection, Nicolaus Copernicus University, Lwowska 1, 87-100 Toruń, Poland e-mail: swiontek@umk.pl

U. Jankiewicz

Department of Biochemistry, Warsaw University of Life Sciences, SGGW, 02-776 Warsaw, Poland fungicides have many disadvantages. Biological control, the use microorganisms to control plant diseases, offers an alternative, environmentally friendly strategy for controlling phytopathogens. Recently, biological control has been focused on microorganisms producing mycolytic enzymes, especially chitinases (CHIs), which are known to hydrolyze chitin, a major component of fungal cell walls. CHIs or chitinolytic microorganisms are currently being studied as an attractive alternative to synthetic chemicals because of their perceived safety and lower environmental impact. Biological control strategies have become an important approach for facilitating sustainable agriculture $[40,54$, 80, 92].

\section{Occurrence of Chitin in Nature}

Chitin, a $\beta$-(1,4)-linked polymer of $N$-acetyl-D-glucosamine, is one of the most abundant naturally occurring polysaccharides. Chitin occurs in combination with other polymers, such as proteins. In nature, it is found in two crystalline forms. The $\alpha$-form has antiparallel chitin microfibrils with strong intermolecular hydrogen bonding and is the most abundant chitin in nature, found in shrimps and crabs. $\beta$-chitin has parallel chitin chains and occurs in squid pens [125]. Chitin is widely distributed in nature, particularly as a structural polysaccharide in fungal cell walls, the exoskeletons of arthropods, the outer shells of crustaceans, and nematodes. Approximately $75 \%$ of the total weight of shellfish, such as shrimp, crab, and krill, is considered waste. Chitin comprises $20-58 \%$ of the dry weight of this waste [116]. Chitin has a broad range of applications in the biochemical, food, and chemical industries and shows antimicrobial, anticholesterol, and antitumor activity $[32,77]$. Chitin and its related materials 
are also used in wastewater treatment [26], drug delivery, and wound healing and as dietary fiber [19, 74]. Waste from the processing of marine crustaceans is a significant commercial source of chitin. Substantial amounts are produced in Asia, mainly Thailand, which is a major exporter of shrimp, and India. Utilization of waste chitin is rare, but if properly conducted, would solve the environmental problem of waste disposal and enable the great economic value of chitin to be utilized [117]. It is worth noting that the production of chitin in the marine biosphere is enormous. The estimated annual amount of chitin produced by marine zooplankton is over several billions of tons [8], and the total annual production of chitin is estimated to be $10^{10}$ to $10^{11}$ tons $[31,42]$. Most of this production is in chitin shells embedded in marine zooplankton and marine crustaceans such as shrimp, crabs, and lobsters. When molted, the shed exoskeletons may contain up to five times more chitin than the body of the animal. Arthropods have the largest operational significance because they produce the greatest amount of chitin. Similarly, the surface layer of the bodies of terrestrial insects and arachnids contains considerable amounts of chitin [119]. Surprisingly, the chitin content in marine sediment is quite low. This is due to bioconversion processes carried out by marine chitinolytic bacteria [37], which transform this polysaccharide into organic compounds that are subsequently used by other microorganisms as a source of carbon and nitrogen.

\section{Chitinolytic Microorganisms}

Commonly found in the biosphere, chitinolytic microorganisms are capable of decomposing chitin under both aerobic and anaerobic conditions. They are found in many different environments. Contrary to the expectation that they abound in environments with high amounts of chitin (such as shrimp shells), only a small number have been identified in shrimp waste: chitinolytic bacteria comprise only $4 \%$ of the total heterotrophic bacteria. Chitinolytic fungi comprise $25-60 \%$ of the total mold fungi, but their number is lower than the number of bacteria [106]. While investigating the correlation between shrimp waste and the number of bacteria in the digestive tract of lambs, Cobos et al. [13] identified only a small percentage of chitinolytic bacteria in this environment. They identified no chitinolytic bacteria after 30 days of feeding the lambs a diet containing no or $15 \%$ shrimp waste. Only after 72 days of feeding the lambs on a diet containing $25 \%$ of powdered shrimp waste did they note $0.1 \%$ of chitinolytic bacteria in the lamb's digestive tracts.

Chitin substrates do not always stimulate the growth of chitinolytic microorganisms. The results obtained by Zdanowski and Vosjan [123] indicate that chitinolytic microorganisms are only a small percentage of the total microbial population on krill shells. Substantially higher numbers were identified in lakes and soil within the lakes' drainage basins. Soil and the rhizosphere are heavily colonized by chitinolytic microorganisms, and actinomycetes are the most abundant. Swiontek Brzezinska et al. [108] maintain that $45-69 \%$ of actinomycetes and $32-40 \%$ of mold fungi were able to decompose chitin in the soil within the drainage basin of Lake Chełmżyńskie. Because chitinolytic microorganisms isolated from soil were usually more active that chitinolytic bacteria isolated from water and bottom sediments, they could be more appropriate for agricultural use. Paul and Clark [78] report that 90\% of all actinomycetes isolated from soil is of the genus Streptomyces. Almost all actinomycetes are saprophytes capable of decomposing lignin, chitin, pectin, and creatine. Soil bacteria able to degrade chitin include Flavobacterium, Bacillus, Cytophaga, Pseudomonas. Chitin-degrading fungi include, for example Aspergillus, Mucor, and Mortierella [90].

In aquatic environments, chitin is decomposed primarily by heterotrophic bacteria. These include aerobic bacteria of the genera Aeromonas, Enterobacter, Chromobacterium, Arthrobacter, Flavobacterium, Serratia, Bacillus, Erwinia, Vibrio [20, 102]. According to Swiontek Brzezinska et al. [107], $15 \%$ of bacteria decomposed chitin in eutrophic Lake Chełmżyńskie. However, in the bottom sediments of this lake, a much lower number of chitinolytic microorganisms were identified. Mudryk [71], in surface water of Lake Gardno, found that $10.6 \%$ of bacteria degraded chitin, compared with only $5 \%$ in sediment.

Chitinolytic microorganisms inhabit a wide range of environments. Kopečny et al. [56] found chitinolytic bacteria in the feces of wild herbivores (e.g., bison-Bibos bonasus, llama-Llama vicugna paca, and elk-Elaphurus davidianus) and domestic herbivores (e.g., sheep and cow). They were also found in the rumen fluid of cows, which are unable to produce enzymes for digesting chitin and thus offer a living environment for chitinolytic bacteria in exchange for help digesting this tough compound. The majority of the identified bacteria belonged to the genus Clostridium, whose most common strain, Clostridium sp. ChK5, decomposes colloidal chitin and produces acetate, a salt of butyric acid, and lactate.

There is little information on the participation of anaerobic microorganisms in the degradation of chitin, although chitynolityc bacteria of the genus Clostridium have been described in marine environments $[8,110]$ and Gram-negative, anaerobic bacteria are present in sediment [79]. The results obtained by Reguera and Leschine [84] suggest that the use of chitin as a source of nitrogen may be widely distributed among anaerobic and aerobic cellulolytic microbes. Cellulomonas (ATCC 21 399) is capable of 
rapid degradation of cellulose and chitin both aerobically and anaerobically. Sturz and Robinson [99] observed that the degradation of chitin occurs mainly in surface sediments, where aerobic bacteria dominate and play a decisive role in its degradation.

\section{Chitinolytic Enzymes}

CHIs are glycoside hydrolases that catalyze the decomposition of chitin. They are produced by microorganisms, fungi, insects, plants, and animals and are also found in human blood serum [30]. They hydrolyze the $\beta-1,4-$ glycosidic bonds between the $N$-acetyl-D-glucosamine residues that comprise a chitin chain [41]. Complete enzymatic hydrolysis of chitin to free $\mathrm{N}$-acetylglucosamine is performed by a chitinolytic system consisting of a diverse group of enzymes that catalyze the hydrolytic polymerization of chitin [25, 30, 77, 91].

The nomenclature of chitinolytic enzymes is not clear. Due to the location of the hydrolyzed bond, CHIs (EC 3.2.1.14) can be divided into two categories. Endochitinases cleave chitin chains in random locations, generating low molecular weight oligomers, such as chitototetriose, chitotriose, and diacetylochitobiose. Exochitinases release chitobiose from the reducing or non-reducing end of the chitin chain. In the past, there were two other classes for these enzymes: chitobiases are responsible for the hydrolysis of chitobiose, and $\beta$ - $N$-acetylglucosaminidases produce monomers of $\beta$ - $N$-acetyl-D-glucosamine [14, 88]. Currently, according to the nomenclature established by the Nomenclature Committee of the International Union of Biochemistry and Molecular Biology, chitobiase and $\beta-N$ acetylglucosaminidases are included in the common set of $\beta$ - $N$-acetylhexosaminidases (EC.3.2.1.52) [14, 88].

When classified by the similarity of amino acid sequences, CHIs can be divided into three families: 18, 19, and 20. Family 18 includes CHIs derived mainly from fungi but also from bacteria, viruses, animals, insects, and plants. Family 19 includes CHIs derived from plants (class I, II, and IV) and several derived from bacteria, e.g., Streptomyces griseus. Family 20 includes $N$-acetylglucosaminidase from Vibrio harveyi and $\mathrm{N}$-acetylhexosaminidase from Dictyostelium discoideum and human [16, 21, 41, 77]. Many bacteria, including Serratia marcescens, Aeromonas sp., Pseudomonas aeruginosa K-187, and S. griseus HUT 6037, can synthesize several different CHIs [45, 101, 112, 116]. Moreover, the well-recognized mold fungus Trichoderma harzianum produces two $\mathrm{N}$-acetylglucosaminidases, four endochitinases, and one chitobiosidase [38].

Microbial CHIs weigh from 20 to $120 \mathrm{kDa}$, with most 20-60 kDa $[49,51]$. The optimum $\mathrm{pH}$ and temperature of
CHIs are 5-8 and $\sim 40{ }^{\circ} \mathrm{C}$, respectively. Depending on the origin of the $\mathrm{CHI}$, its activity can be inhibited or stabilized by the presence of various metal ions (Table 1). A strong inhibitor of CHIs is allosamidin, which was first reported as a specific, competitive inhibitor of insect CHI. Allosamidin has a structure similar to that of an intermediate substrate, an oxazoline ring that may be formed between the carbonyl oxygen of the $\mathrm{N}$-acetyl group and the $\mathrm{C}-1$ of $\mathrm{N}$-acetylglucosamine during hydrolysis [55].

CHIs are inducible (adaptive) enzymes, i.e., they are expressed only under certain conditions induced by a certain factor(s) and are regulated by a repressor/inducer system. While chitin is an inducer, glucose or another easily assimilable source of carbon may be a repressor [86]. Frändberg and Schnürer [27] maintain that the production of CHIs may be induced by chitin and chitooligosaccharides in the medium; however, no extracellular production of CHIs was observed in the absence of these compounds. Although some actinomycetes produce CHIs constitutively, an appropriate chitin substrate always increases production [77]. Inducing the production of CHIs through different chitin substances is a feature of a particular enzyme-producing strain. Numerous studies use colloidal chitin for the production of CHIs [44, 63]. However, some microorganisms can produce active CHIs in the presence of shrimp shells $[10,117]$. The results of laboratory research aimed at evaluating the enzymatic activity of Trichoderma indicate that a medium containing purified chitin or mycelium as the sole source of carbon provides optimum growth conditions for inducing extracellular CHIs. Studies using different carbon substrates have confirmed the relationship between a metabolized source of carbon and the synthesis of chitinolytic enzymes. Chitinolytic activity was observed in bacteria cultured on media containing colloidal or glycol chitin, $\mathrm{N}$ acetylglucosamine, chitooligosaccarides, or the cell walls of certain fungi. No or minimal activity was observed in the same bacteria cultured on media containing glucose or laminarin as the source of carbon [69, 88, 124]. Molecular studies have detected the presence of a two-component signal transduction system that regulates the synthesis of CHIs in Pseudoalteromonas piscicida O-7, Streptomyces thermoviolaceus OPC-520, and other bacteria. The systems consist of two proteins: a histidine kinase and a response regulator. In response to a signal from the environment (the presence of chitin or its derivatives), a bacterial kinase undergoes autophosphorylation at a histidine residue, then catalyzes the transfer of a phosphate group to an asparagine residue in the sequence of a response regulator. The phosphorylated response regulator is combined with a promoter sequence and activates the transcription of genes encoding CHI [87, 88, 111]. 
Table 1 Biochemical properties of several microbial CHIs

\begin{tabular}{|c|c|c|c|c|c|c|c|}
\hline Microorganism & Enzyme type & $\begin{array}{l}\text { Mol. wt. } \\
\text { (kDa) }\end{array}$ & $\begin{array}{l}\text { Temp. } \\
\left({ }^{\circ} \mathrm{C}\right)\end{array}$ & $\mathrm{pH}$ & Inhibitor & Activator & Reference \\
\hline Serratia sp. KCK & Exochitinase & 57 & 40 & $5-10$ & $\begin{array}{l}\mathrm{Pb}^{2+}, \mathrm{Fe}^{2+}, \mathrm{Zn}^{2+} \\
\mathrm{Hg}^{2+}, \mathrm{Mg}^{2+}\end{array}$ & - & {$[53]$} \\
\hline Pseudomonas sp. TKU015 & - & 68,30 & 50 & $5-7$ & $\begin{array}{l}\mathrm{Mn}^{2+}, \mathrm{Fe}^{2+}, \mathrm{Cu}^{2+} \\
\text { EDTA }\end{array}$ & $\begin{array}{c}\mathrm{Zn}^{2+}, \mathrm{SDS}, \\
\text { Tween 40, } \\
\text { Triton } \\
\mathrm{X}-100\end{array}$ & [118] \\
\hline Bacillus sp. 13.26 & - & 60 & 60 & $7-8$ & $\mathrm{Mn}^{2+}, \mathrm{Co}^{2+}, \mathrm{Ca}^{2+}$ & $\mathrm{Mg}^{2+}, \mathrm{Ni}^{2+}$ & {$[122]$} \\
\hline Bacillus licheniformis & - & & $50-70$ & $5-6$ & - & $\mathrm{Ca}^{2+}$ & {$[52]$} \\
\hline $\begin{array}{l}\text { Bacillus thuringiensis spp. } \\
\text { colmeri } 15 \mathrm{~A} 3\end{array}$ & - & 36 & $20-60$ & $4-8$ & $\mathrm{Ag}^{+}, \mathrm{Zn}^{2+}$ & $\begin{array}{l}\mathrm{Mg}^{2+}, \mathrm{Na}^{+}, \\
\mathrm{Fe}^{3+}, \mathrm{Ca}^{2+}, \\
\mathrm{Cu}^{2+}\end{array}$ & [61] \\
\hline Bacillus subtilis NPU 001 & Endochitinase & 31 & 50 & 6 & $\mathrm{Hg}^{2+}$ & - & {$[10]$} \\
\hline Bacillus brevis & Endochitinase & 85 & 60 & 8 & $\mathrm{Ag}^{+}$ & - & {$[62]$} \\
\hline Stenotrophomonas maltophilia & $\begin{array}{c}\text { Endochitinase, } \\
\text { exochitinase }\end{array}$ & 52 & $40-50$ & $5-7$ & $\mathrm{Hg}^{2+}, \mathrm{Cu}^{2+}$ & $\mathrm{Ca}^{2+}, \mathrm{Mg}^{2+}$ & {$[46,100]$} \\
\hline $\begin{array}{l}\text { Sanguibacter antarcticus } \\
\text { KOPRI } 21702 \mathrm{~T}\end{array}$ & Endochitinase & 55 & $30-40$ & 7.6 & - & $\begin{array}{l}\mathrm{Cu}^{2+}, \mathrm{Ca}^{2+}, \\
\mathrm{Ba}^{2+}\end{array}$ & [76] \\
\hline Streptomyces sp. DA11 & - & 34 & 50 & 8 & $\begin{array}{l}\mathrm{Fe}^{2+}, \mathrm{Ba}^{2+}, \text { EDTA, } \\
\text { EGTA, SDS, urea }\end{array}$ & $\begin{array}{l}\mathrm{Mn}^{2+}, \mathrm{Cu}^{2+} \\
\mathrm{Mg}^{2+}\end{array}$ & [37] \\
\hline Streptomyces halstedii AJ-7 & - & 55 & 50 & 7 & $\mathrm{Hg}^{2+}, \mathrm{Ni}^{2+}, \mathrm{Pb}^{2+}$ & $\mathrm{Co}^{2+}$ & [49] \\
\hline Streptomyces roseolus DH & GH-18 & 40 & 60 & $6-8$ & $\mathrm{Cu}^{2+}, \mathrm{Co}^{2+}, \mathrm{Mn}^{2+}$ & $\begin{array}{l}\mathrm{Ca}^{2+}, \mathrm{Ba}^{2+} \\
\mathrm{Mg}^{2+}\end{array}$ & [47] \\
\hline Streptomyces venezuelae $\mathrm{P} 10$ & - & 66 & $30-40$ & $6-8$ & - & - & [73] \\
\hline $\begin{array}{l}\text { Streptomyces aureofaciens } \\
\text { CMUAc } 130\end{array}$ & - & 40 & $30-40$ & $6.5-7$ & $\mathrm{Hg}^{2+}, \mathrm{Cd}^{2+}, \mathrm{Ni}^{2+}$ & $\mathrm{Mg}^{2+}$ & [109] \\
\hline Penicillium sp. LYG 0704 & - & 47 & 40 & 5 & $\mathrm{Fe}^{2+}, \mathrm{Hg}^{2+}$ & $\mathrm{Mg}^{2+}, \mathrm{Mo}^{2+}$ & [59] \\
\hline \multirow[t]{2}{*}{ Massilia timonae } & Endochitinase & 56 & 55 & 5 & $\mathrm{Hg}^{2+}$ & $\mathrm{Mn}^{2+}$ & [1] \\
\hline & Both & 64 & 60 & Both & Both & Both & \\
\hline Trichoderma saturnisporum & Chitobiosidase & 24 & 60 & 4 & - & $\mathrm{Mn}^{2+}, \mathrm{Zn}^{2+}$ & [93] \\
\hline $\begin{array}{l}\text { Trichoderma atroviride } \\
\text { PTCC5220 }\end{array}$ & - & 42 & 40 & 5 & - & - & [39] \\
\hline Aspergillus fumigatus CS-01 & - & 45 & 55 & 5 & - & - & {$[121]$} \\
\hline $\begin{array}{l}\text { Thermomyces lanuginosus } \\
\text { SY2 }\end{array}$ & - & 48 & 55 & 4.5 & $\begin{array}{l}\mathrm{Fe}^{2+}, \mathrm{Ag}^{+}, \mathrm{Hg}^{2+} \\
\mathrm{Cu}^{2+}, \text { EDTA }\end{array}$ & $\begin{array}{l}\mathrm{Ca}^{2+}, \mathrm{Ba}^{2+}, \\
\mathrm{Na}^{+}, \mathrm{K}^{+}\end{array}$ & [34] \\
\hline
\end{tabular}

\section{Decomposition of Shrimp Waste, the Main Source of Chitin}

The decomposition of chitin, an important part of the global carbon and nitrogen cycles [43], relies mainly on microbiological processes. Chitin can be used by microbial populations as the sole source of these two elements [67]. Considered common waste, shrimp waste (the main source of chitin) is processed for animal feed and is also used in agriculture as a cheap natural nitrogen fertilizer. However, it is not uncommon for shrimp waste to travel from a drainage basin to stagnant waters, where it is decomposed by different microorganisms. Swiontek Brzezinska et al. [106] determined the decomposition rate by evaluating oxygen consumption by the microorganisms present in shrimp waste. In this study, they used cephalic segments containing significant amounts of fat and protein and shells containing no fat or protein. The results of their study indicated that the decomposition rate was very high, with a relatively high oxygen consumption, which is typical of this type of environment. Due to the content of chitin and other components, the oxidation of shrimp shells was slower and less intense when compared to the oxidation of other parts.

In the water and bottom sediments of a highly eutrophic lake, shrimp waste was efficiently metabolized by planktonic and benthic microorganisms. Oxygen consumption in the presence of shrimp waste was higher in the bottom sediments than in the water, and this difference was associated with the higher accumulation of microorganisms in the sediment [107]. In addition, Streptomyces rimosus isolated from soil effectively metabolized not only shrimp 
waste but also chitosan, a chitin derivative. After culturing for 14 days, the decomposition rate of chitosan was $42.5 \%$, and the decomposition rate of shrimp shells was $38.2 \%$. Considering that these materials are difficult to decompose, the results can be regarded as satisfactory [105]. When Hoang et al. [43] studied the decomposition of shrimp shells by Streptomyces sp. TH-11, they noticed a substantial reduction in the weight of the shells as early as the 7th, 12th, and 16th days. Similar to other macromolecular compounds, chitin is not easily metabolized, even by chitinolytic microorganisms, because its oxidation requires time. According to Mudryk [72] and Grover and Chrzanowski [33], cellulose, similar in structure to chitin, is not widely used as a respiratory substrate, and only a small number of microorganisms can decompose this polymer.

Shrimp shell waste is tested primarily for the production of bioactive monosaccharides and oligosaccharides [18] such as $\mathrm{N}$-acetylglucosamine, which is used for the production of cosmetics and nutritional supplements [12]. Shrimp shell is also a substrate for the production of CHIs. Actinomycetes and several species of bacteria use shrimp shells more effectively than colloidal chitin for the synthesis of CHIs. In addition, Rattanakit et al. [83] maintain that shrimp shell waste is a good substrate for culturing Aspergillus sp. S1-13, which, when grown on media containing shrimp waste, synthesizes the same or higher amounts of chitinolytic enzymes than the fungus grown on medium supplemented with colloidal chitin. Wang et al. [115], Chang et al. [10], and Wang and Chang [116] who investigated the chitinolytic activity of bacteria in the Bacillus and Pseudomonas genera used successfully shrimp and crab shell waste to produce CHIs.

\section{Microbiological CHIs in Biological Control}

Storage fungi perform a very important role in the operation of ecosystems. As saprophytic organisms they degrade organic matter, leading to formation of humic substances. Nonetheless, many of these fungi are parasites and pathogens. The ones which attack crop plants are particularly dangerous. The most important plant pathogens include: Fusarium, Penicillium, Alternaria, Botrytis, Ramularia, Monilinia, Cladosporium, and Aspergillus. These molds attack many horticultural plants, including vegetables, fruit, and decorative flowers. In order to protect the crops people apply different types of crop protection chemicals (fungicides) produced in chemical synthesis. There are also many biological agents fighting fungal pathogens, containing various bio-active substances of microbiological origin, e.g., CHIs.

Abilities of microorganisms to produce antifungal CHIs are widely known (Table 2 ). The enzymes produced by the genus of storage fungi called Trichoderma are of significant biotechnological importance. The mechanism of their activities is well-known [5]. Application of preparations containing this mold in biological control of fungi development is possible as a result of production of such enzymes as CHIs or glucanases $[2,38,58]$. The exo- $\alpha-1.3$ glucanase was able to bind to cell walls of various phytopathogenic fungi, such as Aspergillus niger, Botrytis cinerea, Colletotrichum acutatum, Fusarium oxysporum, Penicillum aurantiogriseum, or Rhizoctonia solani [2]. The CHI effectively inhibit the growth of $R$. solani, Marchophominia phaseolina, Fusarium sp. [4, 70, 75].

Moreover, CHIs of bacterial origin were also found out to show fungicidal properties. For instance, CHIs Bacillus thuringiensis spp. colmeri inhibit growth of many phytopathogens, including $R$. solani, B. cinerea, Penicillium chrysogenum, and Physalospora piricola [61]. Prasanna et al. [81] stated that CHIs from Brevibacillus laterosporus effectively inhibited development of Fusarium equiseti. These types of enzymes also showed insecticidal properties. Some yeast, e.g., Pichia anomala or Pichia membranefaciens, possess fungicidal properties as well. Their $\beta-1.3$-glucanases inhibited the growth of B. cinerea [48, 65]. Development of this mold was also effectively inhibited by the CHIs produced by the following yeast: Candida saitoana, C. guilliermondii, and C. oleophila [23, 89].

Actinomycetes also display strong fungicidal properties. It is related to the production of many types of various fungicidal compounds, including antibiotics and extracellular hydrolytic enzymes such as CHIs and $\beta-1.3$-glucanases [80]. Streptomyces halstedii, S. griseus, and $S$. cavourensis SY224 produce highly active antifungal CHIs, which implies the possibility of using them as agents for biological protection of crops [29, 49, 60].

With the use of genetic engineering techniques it is also possible to use in the biocontrol of phytopathogens the recombined enzymes obtained by introduction of proper genes encoding antifungal CHIs into various types of organisms. In the research performed by Bezirganoglu et al. [6] antifungal protein (AFP) and CHI fusion genes were introduced into oriental melons to control fungal diseases caused by $R$. solani and $F$. oxysporum. Their results demonstrated that the AFP-CHI fusion gene was effective in protecting the transgenic melon plants against fungal disease caused by $R$. solani and $F$. oxysporum. Matroodi et al. [66] have constructed a chimeric CHI by addition of chitin-binding domain from $S$. marcescens to the fungal CHI, Trichoderma atroviride Chit42, to study the role of chitin-binding domain in enzyme activity of Chit42. The evaluation of the antifungal activity of the constructed chimeric and native CHIs was performed to study the effect of ChBD in the antifungal activity of the 
Table 2 Antifungal activity of some microbial CHIs

\begin{tabular}{|c|c|c|}
\hline Source & Antagonistic against & References \\
\hline Trichoderma harzianum Rifai TM & Fusarium oxysporum $f$. sp. melonis, Sclerotium rolfsii & [114] \\
\hline Trichoderma harzianum & $\begin{array}{l}\text { Macrophomina phaseolina, Fusarium sp. R. solani, Aspergillus } \\
\text { niger (NCIM 563), Aspergillus, Rhizopus, Mucor sp. }\end{array}$ & {$[4,70,75]$} \\
\hline Trichoderma atroviride PTCC5220 & Rhizoctonia solani & [39] \\
\hline Trichothecium roseum & Alternaria alternata, Fusarium moniliforme, Magnaporthe grisea & {$[22]$} \\
\hline Basidiobolus ranarum & Rhizoctonia solani, $F$. solani. & {$[68]$} \\
\hline Bacillus sp. BG-11 & $\begin{array}{l}\text { Rhizopus arrhizus, Sclerotium rolfsii, } R \text {. solani, Phytophthora } \\
\text { infestans, } F \text {. oxysporum, Phanerochaete chrysosporium }\end{array}$ & [7] \\
\hline Bacillus cereus YQQ 308 & Fusarium oxysporum, $F$. solani, $P$. ultimum & [11] \\
\hline Bacillus pumilus SG2 & $\begin{array}{l}\text { Fusarium graminearum, } R \text {. solani, Magnaporthe grisea, } \\
\text { Sclerotinia sclerotiorum, Trichoderma reesei, B. cinerea, } \\
\text { Bipolaris sp. }\end{array}$ & {$[28]$} \\
\hline Bacillus cereus $\mathrm{IO} 8$ & Botrytis cinerea & {$[36]$} \\
\hline Bacillus thuringiensis subsp. colmeri $15 \mathrm{~A} 3$ & $\begin{array}{l}\text { Rhizoctonia solani, } B . \text { cinerea, } P \text {. chrysogenum, } P \text {. piricola, } \\
\text { Penicillium glaucum, Sclerotinia fuckelian }\end{array}$ & {$[61]$} \\
\hline Brevibacillus laterosporus & Fusarium equiseti & {$[81]$} \\
\hline Aeromonas hydrophila SBK1 & Aspergillus flavus, F. oxysporum & {$[35]$} \\
\hline Enterobacter sp. NRG4 & $\begin{array}{l}\text { Fusarium moniliforme, Aspergillus niger, Mucor rouxi, Rhizopus } \\
\text { nigricans }\end{array}$ & {$[17]$} \\
\hline Alcaligenes xylosoxydans & Fusarium sp. Rhizoctonia bataticola & [113] \\
\hline Stenotrohomonas maltophila & Fusarium solani, $F$. oxysporum, $R$. solani, A. alternata & {$[46,100]$} \\
\hline Rhizobium sp & $\begin{array}{l}\text { Aspergillus flavus, Aspergillus niger, Curvularia lunata, } F \text {. } \\
\text { oxysporum, Fusarium udum }\end{array}$ & {$[97]$} \\
\hline Serratia marcescens strain B2 & Botrytis cinerea & [95] \\
\hline Vibrio pacini & $\begin{array}{l}\text { Mucor racemosus, Trichoderma viride, Zygorhynchus } \\
\text { heterognmus, Candida albicans }\end{array}$ & [3] \\
\hline Streptomyces halstedii AJ-7 & Alternaria alternata, B. cinerea, $S$. lycopersici, $F$. oxysporum & [49] \\
\hline Streptomyces hygroscopicus & Colletotrichum gloeosporioides, Sclerotium rolfsii & {$[80]$} \\
\hline Streptomyces tendae TK-VL_333 & Aspergillus niger, $F$. oxysporum & {$[51]$} \\
\hline Streptomyces sp. DA11 & Aspergillus niger, Candida albicans & {$[37]$} \\
\hline Streptomyces roseolus DH & Aspergillus spp., Rhizopus chinensis, Penicillium spp., Mucor spp. & [47] \\
\hline Streptomyces sporovirgulis & Alternaria alternata & [104] \\
\hline Streptomyces rimosus & Alternaria alternata, $F$. solani & {$[105]$} \\
\hline
\end{tabular}

chimeric CHI. Their study demonstrated that the fusion of ChBD improved the affinity to crystalline and colloidal chitin and also the enzyme activity of the chimeric $\mathrm{CHI}$ when compared with the native Chit42. The chimeric $\mathrm{CHI}$ showed higher antifungal activity toward phytopathogenic fungi.

Effectiveness of enzymatic agents in fighting fungal phytopathogens depends on many factors. Roberts and Selitrennikoff [85] discovered that CHIs of bacterial origin show considerably lower fungicidal activity than those of plant origin. The authors associated this phenomenon with the fact that the majority of bacterial CHIs are exochitinases whose activity is lower by one or two orders than that of endochitinases.

At the same time the fungicidal activity may be related to interaction of different types of enzymes. Research by
Someya et al. [95] proved that synergic activity of endochitinase and chitobiase produced by Serratia marcescens inhibits the development of $B$. cinerea to a larger extent than either enzyme individually. Chang et al. [11] stated that Bacillus cereus QQ308 produced antifungal hydrolytic enzymes, comprising $\mathrm{CHI}$, chitosanase, and protease, when grown in a medium containing shrimp and crab shell powder produced from marine waste. The growth of the plant-pathogenic fungi $F$. oxysporum, $F$. solani, and Pythium ultimum was considerably affected by the presence of the QQ308 culture supernatant. Certain genera of mold producing very strong endochitinases-T. harzianum and Fusarium chlamydosporum are of particular significance in protection of plants. Apart from chitnases, they also produce other hydrolytic enzymes, e.g., proteases, which perfectly interact with the chitin-decomposing enzymes [82]. 
Joo [49], testing fungicidal activity of purified and nonpurified CHIs produced by $S$. halstedii, demonstrated that the enzymatic preparation inhibited the growth of several genera of fungal phytopathogens, to a greater or lesser extent. Purified CHIs inhibited development of Alternaria alternata, Colletotrichum gloeosporioides, Fusarium oxysporium, and Stemphylum lycopersici mycelia, and nonpurified ones additionally caused the growth inhibition of Phytophtora capsci. Swiontek Brzezinska et al. [103, 104] found out in plate tests that the level of inhibition of the phytopathogenetic growth depended on the purity level of the enzymatic preparation. The CHIs which were not subject to purification turned out to be more powerful antagonists than the purified CHIs. It is probably connected with the presence of non-purified antibiotics which increase the fungicidal activity of the agents. Synergic interaction between $\beta$-1.3-glucanases and peptide antibiotics (peptabols) was revealed in the process of parasitism of T. harzianum. Peptabols and trichorzianines A and B are capable of inhibiting $\beta$-glucan synthetases (enzymes responsible for the synthesis of $\beta$-glucan in the cell wall) isolated from the plasmalemma of $B$. cinerea. The effects of peptabols may be strengthened by addition of $\beta-1.3-$ glucanases produced by $T$. harzianum, which increases their fungicidal effectiveness [64, 120].

\section{Problems Associated with the Use of Microorganisms and Their Metabolites in Plant Protection Against Fungal Diseases}

Biopreparations offer an alternative, environmentally friendly strategy for controlling phytopathogens. However, due to several challenges, their application is still limited. Although highly beneficial, the use of microorganisms and their metabolites also has some disadvantages. First, compared to chemical products, biological fungicides require more time to work. Moreover, due to their high selectivity, the costs associated with their use are relatively high [126]. The environmental conditions, which determine the growth of microorganisms, must also be considered. However, there are many ways in which different biofungicides can be combined or implemented using agricultural, physical, and chemical methods to produce a synergistic effect $[57,96]$.

Dahiya et al. [16] believe that chitinolytic enzymes can be used as supplements for chemical fungicides to increase their effectiveness against pathogenic molds and reduce the required concentrations of these harmful chemicals. In agriculture, the reluctance to use fungicides based on CHIs is associated with the fear that their impact will be reduced in the natural environment. However studies have shown that the combination of two chitinolytic bacteria Paenibacillus sp. 300 and Streptomyces sp. 385 is more effective against $F$. oxysporum causing cucumber wilt than individual strains or other combinations [94]. According to El-Tarabily et al. [24] the combination of $S$. marcescens, Streptomyces viridodiasticus, and Micromonospora carbonacea strains effectively inhibited the growth of Sclerotinia minor responsible for vegetable rot. Kishore et al. [54] described a synergistic effect of Bacillus circulans GRS 243 and S. marcescens GPS 5 , the combination which inhibited the growth of the mold fungus Phaeoisariopsis personata when used as a prophylactic on the leaves. Forest protection relies on biofungicides containing Trichoderma species (mainly $T$. viride and $T$. harzianum), whose spores effectively inhibited the growth of fungi causing canker when mixed with beech sawdust and applied to the soil [50]. Agriculture relies on biofungicides containing various microorganisms (e.g., Bacillus subtilis GB03, Pseudomonas aureofaciens Tx-1, and Streptomyces griseoviridis $\mathrm{K} 61$ ), which are sold under different trade names [15]. The majority of biofungicides rely on colonizing the rhizosphere with microorganisms. By producing fungicidal enzymes and other metabolites, these microorganisms inhibit the growth of pathogens and protect plant roots.

\section{Conclusions}

Chitinolytic microorganisms for a potential biotechnological application may be produced in various natural environments. Their application is not limited to degradation of the waste containing chitin. Numerous studies demonstrated the possibility of using them in production of chitinolytic enzymes with fungicidal activity against some fungal phytopathogens. In biological control of fungal phytopathogens, application of agents containing various metabolites of microorganisms, including CHIs, appears to be the more efficient, since they show stronger fungicidal activity than purified chitinolytic enzymes. The use of agents constituting a consortium of chitinolytic microorganisms seems to bring better results in fighting fungal phytopathogens.

Open Access This article is distributed under the terms of the Creative Commons Attribution License which permits any use, distribution, and reproduction in any medium, provided the original author(s) and the source are credited.

\section{References}

1. Adrangi S, Faramarzi MA, Shahverdi AR, Sepehrizadeh Z (2010) Purification and characterization of two extracellular endochitinases from Massilia timonae. Carbohydr Res 345:402-407

2. Ait-Lahsen H, Soler A, Rey M, de la Cruz J, Monte E, Llobell A (2001) An antifungal exo- $\alpha$ 1,3 glucanase (AGN13.1) from the 
biocontrol fungus Trichoderma harzianum. Appl Environ Microbiol 67:5833-5839

3. Bao-qin H, Chang-ying YU, Wan-shun LIU, Ji-xun DAI (2004) Purification and inhibition fungal growth of chitinases from Vibrio pacini. Wuhan Univ J Nat Sci 9(6):973-978

4. Bell DK, Wells HD, Markham CR (1982) In vitro antagonism of Trichoderma species against six fungal plant pathogens. Phytopathol 72:379-382

5. Benitez T, Rincon AM, Limon MC, Codon AC (2004) Biocontrol mechanisms of Trichoderma strains. Int Microbiol 7(4):249-260

6. Bezirganoglu I, Hwang SY, Fang TJ, Shaw JF (2013) Transgenic lines of melon (Cucumis melo L. var. makuwa cv. 'Silver Light') expressing antifungal protein and chitinase genes exhibit enhanced resistance to fungal pathogens. Plant Cell Tissue Organ Cult 112:227-237

7. Bhushan B (1998) Isolation, purification, characterization and scaleup production of a thermostable chitinase from an alkalophilic microorganism. Ph.D. Thesis, Department of Microbiology, Punjab University, Chandigarh

8. Boyer JN (1994) Aerobic and anaerobic degradation and mineralization of ${ }^{14} \mathrm{C}$ : chitin by water column and sediment inocula of the York River estuary, Virginia. Appl Environ Microbiol 60:174-179

9. Budi SW, van Tuinen D, Arnould C, Dumas-Gaudut E, Gianinazzi-Pearson V, Gianinazzi S (2000) Hydrolytic enzyme activity of Paenibacillus sp. strain B2 and effect of antagonistic bacterium on cell wall integrity of two soil-borne pathogenic fungi. Appl Soil Ecol 15:191-199

10. Chang WT, Chen M, Wang SL (2010) An antifungal chitinase produced by Bacillus subtilis using chitin waste as a carbon source. World J Microbiol Biotechnol 26:945-950

11. Chang WT, Chen YC, Jao CL (2007) Antifungal activity and enhancement of plant growth by Bacillus cereus grown on shellfish chitin wastes. Biores Technol 98:1224-1230

12. Chen JK, Shen CR, Liu CL (2010) N-Acetylglucosamine: production and applications. Mar Drugs 8:2493-2516

13. Cobos MA, Garcia LE, González SS, Barcena JR, Hernández DS, Pérez-Sato M (2002) The effect of shrimp shell waste on ruminal bacteria and performance of lambs. Animal Feed Sci Technol 95:179-187

14. Cohen-Kupiec R, Chet I (1998) The molecular biology of chitin digestion. Curr Opin Biotechnol 9:270-277

15. Copping LG (2004) The Manual of biocontrol agents. British Crop Protection Council

16. Dahiya N, Tewari R, Hoondal GS (2006) Biotechnological aspects of chitinolytic enzymes: a review. Appl Microbiol Biotech 25:1-10

17. Dahiya N, Tewari R, Tiwari RP, Hoondal GS (2005) Production of an antifungal chitinase from Enterobacter sp. NRG4 and its application in protoplast production. World J Microbiol Biotechnol 21(8-9):1611-1616

18. Das SN, Neeraja Ch, Sarma PVSRN, Madhu Prakash J, Purushotham P, Kaur M, Dutta S, Podile AR (2012). Microbial chitinases for chitin waste management. Microorg Environ Manag, 135-150

19. Dixon B (1995) Using fungal dressings to heal wounds. Biotechnology 13:120-121

20. Donderski W, Trzebiatowska M (2000) Influence of physical and chemical factors on the activity of chitinases produced by planktonic bacteria isolated from Jeziorak Lake. Pol J Environ Stud 9(2):77-82

21. Duo-Chuan L (2006) Review of fungal chitinases. Mycopathologia 163:345-360

22. Duo-Chuan L, Hang Sh-H, Liu K-Q, Lu J (2004) Purification and partial characterization of a chitinase from the mycoparasitic fungus Trichothecium roseum. J Gen Appl Microbiol 50:35-39
23. El Ghaouth A, Wilson CL, Wisniewski M (1998) Ultrastructural and cytochemical aspects of the biological control of Botrytis cinerea by Candida saitoana in apple fruit. Phytopathology 88:282-291

24. El-Tarabily KA, Soliman MH, Nassar AH, Al-Hassani HA, Sivasithamparam K, McKenna F, Hardy GESTJ (2000) Biological control of Sclerotinia minor using a chitinolytic bacterium and actinomycetes. Plant Pathol 49:573-583

25. Felse PA, Panda T (2000) Production of microbial chitinases: a revisit. Bioprocess Eng 23:127-134

26. Flach J, Pilet PE, Jolles P (1992) What's new in chitinase research? Experimentia 48:701-706

27. Frändberg E, Schnürer J (1994) Chitinolytic properties of Bacillus pabuli K1. J Appl Bacteriol 76:361-367

28. Ghasemi S, Ahmadian G, Jelodar NB, Rahimian H, Ghandili S, Dehestani A, Shariati P (2010) Antifungal chitinases from Bacillus pumilus SG2: preliminary report. World J Microbiol Biotechnol 26:1437-1443

29. Gherbawy Y, Elhariry H, Altalhi A, El-Deeb B, Khiralla G (2012) Molecular screening of Streptomyces isolates for antifungal activity and family 19 chitinase enzymes. J Microbiol 50(3):459-468

30. Gohel V, Singh A, Vimal M, Ashwini P, Chhatpar HS (2006) Bioprospecting and antifungal potential of chitinolytic microorganisms. Afr J Biotechnol 5(2):54-72

31. Gooday GW (1990) The ecology of chitin degradation. Adv Microbial Ecol 11:387-430

32. Gooday GW (1999) Aggressive and defensive roles of chitinases. EXS 87:157-169

33. Grover JP, Chrzanowski TH (2000) Seasonal patterns of substrate utilization by bacterioplankton: case studies in four Temperate lakes of different latitudes. Aquatic Microbial Ecol 23:41-54

34. Guo RF, Shi BSh, Li DCh, Ma W, Wei Q (2008) Purification and characterization of a novel thermostable chitinase from Thermomyces lanuginosus SY2 and cloning of its encoding gene. Agric Sci China 7(12):1458-1465

35. Halder SK, Maity Ch, Jana A, Das A, Paul T, Mohapatra PKD, Pati BR, Mondal KCh (2013) Proficient biodegradation of shrimp shell waste by Aeromonas hydrophila SBK1 for the concomitant production of antifungal chitinase and antioxidant chitosaccharides. Int Biodet Biodeg 79:88-97

36. Hammami I, Siala R, Jridi M, Ktari N, Nasri M, Mohamedali T (2013) Partial purification and characterization of chiIO8, a novel antifungal chitinase produced by Bacillus cereus IO8. J Appl Microbiol 115:358-366

37. Han Y, Yang B, Zhang F, Miao X, Li Z (2009) Characterization of antifungal chitinase from marine Streptomyces sp. DA11 associated with South China Sea Sponge Craniella Australiensis. Mar Biotechnol 11:132-140

38. Haran S, Schickler H, Oppenheim A, Chet I (1995) New components of the chitinolytic system of Trichoderma harzianum. Nucleic Acid Res 99:447-450

39. Harighi MJ, Motallebi M, Zamani MR (2006) Purification of chitinase 42 from Trichoderma atroviride PTCC5220. Iran J Biol 19:203-214

40. Hartl L, Zach S, Seidl-Seiboth V (2012) Fungal chitinases: diversity, mechanistic properties and biotechnological potential. Appl Microbiol Biotechnol 93:533-543

41. Henrissat B (1999) Classification of chitinases modules. EXS 87(1):137-156

42. Herwig RP, Pellerin NB, Irgens RL, Maki JS, Staley JT (1988) Chitinolytic bacteria and chitin mineralization in the marine waters and sediments along the Antarctic Peninsula. FEMS Microbiol Ecol 53:101-112 
43. Hoang KC, Lai TH, Lin CS, Chen YT, Liau CY (2011) The chitinolytic activities of Streptomyces sp. TH-11. Int J Mol Sci 12:56-65

44. Hosny MS, El-Shayeb NA, Abood A, Abdel-Fattah AM (2010) A potent chitinolytic activity of marine Actinomycete sp. and enzymatic production of chitooligosaccharides. Aust J Basic Appl Sci 4(4):615-623

45. Itoh Y, Kawase T, Nikajdou N, Fukada H, Mitsutomi M, Watanabe T, Itoh Y (2002) Functional analysis of the chitin binding domain of a family 19 chitinase from Streptomyces griseus HUT6037: substrate-binding affinity and cis-dominant increase of antifungal function. Biosci Biotechnol Biochem 66:1084-1092

46. Jankiewicz U, Swiontek Brzezinska M, Saks E (2012) Identification and characterization of a chitinase of Stenotrophomonas maltophilia, a bacterium that is antagonistic towards fungal phytopathogens. J Biosci Bioeng 113(1):30-35

47. Jiang X, Chen D, Hong Sh, Wang W, Chen Sh, Zou Sh (2012) Identification, characterization and functional analysis of a GH18 chitinase from Streptomyces roseolus. Carbohydr Polym 87:2409-2415

48. Jijakli MH, Lepoivre P (1998) Characterization of an exo- $\beta-1,3-$ glucanase produced by Pichia anomala strain K, antagonist of Botrytis cinerea on apples. Phytopathology 88:335-343

49. Joo GJ (2005) Purification and characterization of an extracellular chitinase from the antifungal biocontrol agent Streptomyces halstedii. Biotechnol Lett 27:1483-1486

50. Kapuściński R (2002) Biopreparations in environmental protection and use of forest. Environ Eng 7:55-58 (in polish)

51. Kavitha A, Vijayalakshmi M (2011) Partial purification and antifungal profile of chitinase produced by Streptomyces tendae TK-VL_333. Ann Microbiol 61:597-603

52. Khiyami M, Masmali I (2008) Characteristics of thermostable chitinase enzymes of Bacillus licheniformis isolated from Red Palm Weavil Gut. Aus J Basic Appl Sci 2(4):943-948

53. Kim HS, Timmis KN, Golyshin PN (2007) Characterization of a chitinolytic enzyme from Serratia sp. KCK isolated from kimchi juice. Appl Microbiol Biotechnol 6:1275-1283

54. Kishore GK, Pande S, Podile AR (2005) Biological control of late leaf spot of peanut (Arachis hypogaea) with chitinolytic bacteria. Phytopathology 95:1157-1165

55. Koga D, Isogai A, Sakuda S, Matsumoto S, Suzuki A, Kimura S, Ide A (1987) Specific inhibition of Bombyx mori chitinase by allosamidin. Agric Bio Chem 51:471-476

56. Kopečný J, Hodrová B, Stewart CS (1996) The isolation and characterization of rumen chitinolytic bacterium. Lett Appl Microbiol 23:195-198

57. Kordowska-Wiater M (2011) Yeast as a biological plant protection agents. Adv Microbiol 50(2):107-119 (in polish)

58. Kubicek CP, Mach RL, Peterbauer CK, Lorito M (2001) Trichoderma chitinases: from genes to biocontrol. J Plant Pathol 83:11-23

59. Lee YG, Chung KC, Wi SG, Lee JC, Bae HJ (2009) Purification and properties of a chitinase from Penicillium sp. LYG 0704. Protein Expr Purif 65:244-250

60. Lee SY, Tindwa H, Lee YS, Naing KW, Hong SH, Nam Y, Kim KY (2012) Biocontrol of anthracnose in pepper using chitinase, beta-1,3 glucanase, and 2-furancarboxaldehyde produced by Streptomyces cavourensis SY224. J Microbiol Biotechnol 2(10): 1359-1366

61. Liu D, Cai J, Xie Ch-Ch, Liu Ch, Chen Y-H (2010) Purification and partial characterization of a $36-\mathrm{kDa}$ chitinase from Bacillus thuringiensis spp. colmeri, and its biocontrol potential. Enzyme Microb Technol 46:252-256

62. Li S, Zhao ZA, Li M, Gu ZR, Bai C, Huang WD (2002) Purification and characterization of a novel chitinase from Bacillus brevis. Acta Biochemica et Biophysica Sinica 34(6):690-696
63. Mane UV, Deshmukh AM (2009) Chitin degrading potential of three aquatic actinomycetes and its optimization. Afr J Biotechnol 8(23):6617-6620

64. Markovich NA, Kononova GL (2003) Lytic enzymes of Trichoderma and their role in plant defense from fungal diseases: a review. Appl Biochem Microbiol 39:389-400

65. Masih EI, Paul B (2002) Secretion of beta-1,3-glucanase by the yeast Pichia membranefaciens and its possible role in the biocontrol of Botrytis cinerea causing mold disease of the grapevine. Curr Microbiol 44:391-395

66. Matroodi S, Motallebi M, Zamani M, Moradyar M (2013) Designing a new chitinase with more chitin binding and antifungal activity. World J Microbiol Biotechnol 29:1517-1523

67. McCreath KJ, Gooday GW (1992) A rapid and sensitive microassay for determination of chitinolytic activity. J Microbiol Meth 14:229-237

68. Mishra P, Kshirsagar PR, Nilegaonkar SS, Singh SK (2012) Statistical optimization of medium components for production of extracellular chitinase by Basidiobolus ranarum: a novel biocontrol agent against plant pathogenic fungi. J Basic Microbiol 52:539-548

69. Miyamoto K, Okunishi M, Nukui E, Tsuchiya T, Kobayashi T, Imada C, Tsujibo H (2007) The regulator CdsS/CdsR twocomponent system modulates expression of genes involved in chitin degradation of Pseudoalteromonas piscicida strain O-7. Arch Microbiol 188:619-628

70. Monteiro VN, Silva RN, Steindorff AS, Costa FT, Noronha EF, Ricart SAO, Sousa MV, Vainstein MH, Ulhoa CJ (2010) New insights in Trichoderma harzianum antagonism of fungal plant pathogens by secreted protein analysis. Curr Microbiol 61:298-305

71. Mudryk Z (1991) The role of heterotrophic bacteria in the decomposition processes of some macromolecular compounds in the estuarine Gardno lake. Pol Arch Hydrobiol 38:153-162

72. Mudryk Z (1997) Studies on metabolic activity of planktonic bacteria isolated from coastal lake Łebsko. Pol J Environ Stud 6:23-28

73. Mukherjee G, Sen SK (2006) Purification, characterization, and antifungal activity of chitinase from Streptomyces venezuelae P10. Curr Microbiol 53:265-269

74. Muzzarelli RA, Mattioli-Balmonte M, Pugnaloni A, Biagini G (1999) Biochemistry, histology and clinical uses of chitins and chitosans in wound healing. EXS 87:251-264

75. Nampoothiri KM, Baiju TV, Sandhya C, Sabu A, Szakacs G, Pandey A (2004) Process optimization for antifungal chitinase production by Trichoderma harzianum. Process Biochem 39:1583-1590

76. Park HJ, Kim D, Kim IH, Lee CE, Kim IC, Kim JY, Kim SJ, Lee HK, Yim JH (2009) Characteristics of cold-adaptive endochitinase from Antarctic bacterium Sanguibacter antarcticus KOPRI 21702. Enzyme Microb Technol 45:391-396

77. Patil RS, Ghormade V, Deshpande MV (2000) Chitinolytic enzymes: an exploration. Enzyme Microb Tech 26:473-483

78. Paul EA, Clark FE (2000) Soil Microbiology and Biochemistry, University of Maria Curie-Sklodowska University in Lublin (in polish)

79. Pel R, Gottschal JC (1986) Mesophilic chitin: degrading anaerobes isolated from an estuarine environment. FEMS Microbiol Ecol 38:39-49

80. Prapagdee B, Kuekulvong C, Mongkolsuk S (2008) Antifungal potential of extracellular metabolites produced by Streptomyces hygroscopicus against phytopathogenic fungi. Int J Biol Sci 4:330-337

81. Prasanna L, Eijsink VGH, Meadow R, Gåseidnes S (2013) A novel strain of Brevibacillus laterosporus produces chitinases that contribute to its biocontrol potential. Appl Microbiol Biotechnol 97:1601-1611 
82. Punja ZK, Utkhede RS (2003) Using fungi and yeasts to manage vegetable crop diseases. Trends Biotechnol 21:400-407

83. Rattanakit N, Yano Sh, Plikomol A, Wakayama M, Tachiki T (2007) Purification of Aspergillus sp. S1-13 chitinases and their role in saccharification of chitin in mash of solid-state culture with shellfish waste. J Biosci Bioeng 103(6):535-541

84. Reguera G, Leschine SB (2001) Chitin degradation by cellulolytic anaerobes and facultative aerobes from soil and sediments. FEMS Microbiol Lett 204:367-374

85. Roberts WK, Selitrennikoff CP (1988) Plant and bacterial chitinases differ in antifungal activity. J Gen Microbiol 134(169-1):76

86. Sahai AS, Manocha MS (1993) Chitinases of fungi and plants: their involvment in motphogenesis and host-parasite interaction. FEMS Microbiol Rev 11:317-338

87. Saito A, Fujii T, Yoneyama T, Miyashita K (1998) glkA is involved in glucose repression of chitinase production in Streptomyces lividans. J Bacter 180:2911-2914

88. Saks E, Jankiewicz U (2010) Chitinolytic activity of bacteria. Adv Biochem 56(4):1-8 (in polish)

89. Saligkarias ID, Gravanis FT, Epton HAS (2002) Biological control of Botrytis cinerea on tomato plants by the use of epiphytic yeasts Candida guilliermondii strains 101 and US 7 and Candida oleophila strain I-182: II a study on mode of action. Biol Control 25:151-161

90. Schlegel HG (2006) General microbiology. Polish Scientific Publishers, Warsaw, Poland (in polish)

91. Shaikh SA, Deshpande MV (1993) Chitinolytic enzymes: their contribution to basic applied research. World J Microbiol Biotechnol 9:468-475

92. Sharma N, Sharma KP, Gaur RK, Gupta VK (2011) Role of chitinase in plant defense. Asian J Biochem 6:29-37

93. Sharma V, Shanmugam V (2011) Purification and characterization of an extracellular $24 \mathrm{kDa}$ chitobiosidase from the mycoparasitic fungus Trichoderma saturnisporum. J Basic Microbiol 51:1-8

94. Singh PP, Shin YC, Park CS, Chung YR (1999) Biological control of fusarium wilt of cucumber by chitinolytic bacteria. Phytopathology 89:92-99

95. Someya N, Nakajima M, Hirayae K, Hibi T, Akutsu K (2001) Synergistic antifungal activity of chitinolytic enzymes and prodigiosin produced by the biocontrol bacterium Serratia marcescens strain B2 against the gray mold pathogen, Botrytis cinerea. J Gen Plant Pathol 67:312-317

96. Spadaro D, Gullino ML (2005) Improving the efficacy of biocontrol agents against soilborne pathogens. Crop Prot 24:601-613

97. Sridevi M, Mallaiah KV (2008) Factors effecting chitinase activity of Rhizobium sp. from Sesbania sesban. Biologia 63(3):307-312

98. Strange RN, Scott PR (2005) Plant disease: a threat to global food security. Annu Rev Phytopathol 43:83-116

99. Sturz H, Robinson J (1985) Anaerobic decomposition of chitin in freshwater sediments. In: Muzzarelli R, Jeuniaux C, Gooday GW (eds) Chitin in nature and biotechnology. Plenum Press, New York, pp 531-538

100. Suma K, Podile AR (2013) Chitinase A from Stenotrophomonas maltophilia shows transglycosylation and antifungal activities. Biores Technol 133:213-220

101. Suzuki K, Sugawara N, Suzuki M, Uchiyama T, Katouno F, Nikaidou N, Watanabe T (2002) Chitinases, A, B and C1 of Serratia marcescens 2170 produced by recombinant E. coli: enzymatic properties and synergism on chitin degradation. Biosci Biotechnol Biochem 66:1075-1083

102. Swiontek Brzezinska M, Donderski W (2006) Chitinolytic bacteria in two lakes of different trophic status. Pol J Ecol 54(2):295-301
103. Swiontek Brzezinska M, Jankiewicz U (2012) Production of antifungal chitinase by Aspergillus niger LOCK 62 and its potential role in the biological control. Curr Microbiol 65(6):666-672

104. Swiontek Brzezinska M, Jankiewicz U, Lisiecki K (2013) Optimization of cultural conditions for the production of antifungal chitinase by Streptomyces sporovirgulis. Appl Biochem Microbiol 49(2):154-159

105. Swiontek Brzezinska M, Jankiewicz U, Walczak M (2013) Biodegradation of chitinous substances and chitinase production by the soil actinomycete Streptomyces rimosus. Internat Biodet Biodeg 84:104-110

106. Swiontek Brzezinska M, Lalke-Porczyk E, Donderski W (2008) Occurrence and activity of microorganisms in shrimp waste. Curr Microbiol 57:580-587

107. Swiontek Brzezinska M, Lalke-Porczyk E, Donderski W (2008) Utilization of shrimp waste as a respiration substrate by planktonic and benthic microorganisms. Pol J Environ Stud 17(2):273-282

108. Swiontek Brzezinska M, Walczak M, Lalke-Porczyk E, Donderski W (2010) Microbial degradation of shrimp waste in soil of the Chełmżyńskie Lake watershed. Pol J Environm Stud 19(3):627-633

109. Taechowisan T, Peberdy JF, Lumyong S (2003) Chitinase production by endophytic Streptomyces aureofaciens CMUAc130 and its antagonism against phytopathogenic fungi. Ann Microbiol 53(4):447-461

110. Timmis K, Hobbs G, Berkeley RCW (1974) Chitinolytic clostridia isolated from marine mud. Can J Microbiol 20:1284-1285

111. Tsujibo H, Hatano N, Okamoto T, Endo H, Miyamoto K, Inamori Y (1999) Synthesis of chitinase in Streptomyces thermoviolaceus is regulated by a two-component sensor-regulator system. FEMS Microbiol Lett 181:83-90

112. Ueda M, Fujiwara A, Kawaguchi T, Arai M (1995) Purification and some properties of six chitinases from Aeromonas sp. No. 10S-24. Biosci Biotechnol Biochem 59:2162-2164

113. Vaidya RJ, Shah IM, Vyas PR, Chhatpar HS (2001) Production of chitinase and its optimization from a novel isolate Alcaligenes xylosoxydans: potential antifungal biocontrol. World J Microbiol Biotechnol 1:62-69

114. Viterbo A, Haran S, Friesem D, Ramot O, Chet I (2001) Antifungal activity of a novel endochitinase gene (chit36) from Trichoderma harzianum Rifai TM. FEMS Microbiol Lett 200:169-174

115. Wang SL, Chao CH, Liang TW, Chen CC (2009) Purification and characterization of protease and chitinase from Bacillus cereus TKU006 and conversion of marine wastes by these enzymes. Mar Biotechnol 11:334-344

116. Wang SL, Chang WT (1997) Purification and characterization of two bifunctional chitinases/lysozymes extracellularly produced by Pseudomonas aeruginosa K-187 in shrimp and crab shell powder medium. Appl Environ Microbiol 63:380-386

117. Wang SL, Hsiao WJ, Chang WT (2002) Purification and characterization of an antimicrobial chitinase extracellularly produced by Monascus purpureus CCRC31499 in a shrimp and crab shell powder medium. J Agric Food Chem 50:2249-2255

118. Wang SL, Chen SJ, Wang CL (2008) Purification and characterization of chitinase and chitosanases from a new strain Pseudomonas sp. TKU015 using shrimp shells as a substrate. Carbohydr Res 343:1171-1179

119. Witas T (1995) Activity in the exploitation barrier chitin of shellfish. Department of Maritime College Publishing, Szczecin (in polish)

120. Witkowska D, Stolas J, Kancelista A, Piezga M (2009) Lytic abilities of fungi of the genus Trichoderma biomass in the presence of phytopathogens. Acta Pol Sci Biotechnol 8(2):17-25 (in polish) 
121. Xia JL, Xiong J, Xu T, Zhang CG, Zhang RY, Zhang Q, Wu S, Qiu GZ (2009) Purification and characterization of extracellular chitinase from a novel strain Aspergillus fumigatus CS-01. J Cent South Univ Technol 16:0552-0557

122. Yuli PE, Suhartono MT, Rukayadi Y, Hwang JK, Pyun YR (2004) Characteristics of thermostable chitinase enzymes from the Indonesian Bacillus sp 13.26. Enzyme Microbial Technol 35:147-153

123. Zdanowski M, Vosjan J (1998) Anthartic bacteria of sea in UVB radiation condition. Kosmos 47:459-469
124. Zhang Z, Yuen GY, Sarath G, Penheiter AR (2001) Chitinases from the plant disease biocontrol agent Stenotrophomonas maltophilia C3. Phytopatology 91:204-211

125. Zhang M, Haga A, Sekigchi H, Hirano S (2000) Structure of insect chitin isolated from beetle larva cuticle and silkworm (Bombyx mori) pupa exuvia. Int J Biol Macromol 27:99-105

126. Żydlik P (2008) Use of preparations of natural origin in combating certain diseases of fruit plants. Science Technology Nature. Publisher University of Agriculture, Poznan 